\title{
ROME AND ROMAN LAW IN ENGLISH ANTISLAVERY LITERATURE AND JUDICIAL DECISIONS
}

\begin{abstract}
The abolition of slavery by modern states was an important step towards the recognition of what is now known as human rights. The British Empire and its cradle, England, were the leading entities responsible for the support of the international trade slave. For this reason, its antislavery movement is one which deserves particular attention. The argumentation used by the abolitionists has been a subject of many studies. Philosophical, theological or commercial arguments against slavery are well researched. It needs to be emphasised, however, that abolition was a legal step. In this context, it is interesting to seek legal argumentation against the enslavement of people. It is obvious that an appropriate reasoning would be difficult to find. Slavery has been a common social institution since ancient times. The universal principles of Roman law, as well as the significance of Roman civilisation for the development of the Western culture, made it one obvious field of research. The main aim of this article is to check if reference to Roman antiquity has been one of the crucial arguments in the antislavery struggle in Britain.
\end{abstract}

Keywords: English law; Roman law; Slavery; Abolition.

\section{INTRODUCTION}

The main purpose of the article is to investigate the scope of the use of arguments derived from Roman law or connected with Roman slavery during the struggles for the abolition of the slavery in England in the $18^{\text {th }}$ and early $19^{\text {th }}$ centuries. The analysis is divided into three parts. The first part examines the presence of Roman argumentation in the antislavery pamphlets. The second part concerns reference to ancient slavery in legal works. And the third part regards the raising of Roman law arguments in the courtroom.

For modern people, slavery is predominantly a historical subject which they heard about during their history classes in school. ${ }^{1}$ It needs to be emphasised, however, that such condition is relatively new one. No more than two hundred years ago slavery was still a common social phenomenon. And it had existed since Antiquity. It is true that the legal, political, as well as the social conditions of

* University of Łódź, Faculty of Law and Administration, Department of Roman Law, lukasz. korporowicz@wpia.uni.lodz.pl.

${ }^{1}$ Nevertheless, the problem of slavery is not extinct in the modern world (see e.g. Borg Jansson 2015). It still exists in different forms, including disadvantageous employment of chiefly illegal immigrants all other European countries. 
slaves varied greatly in different epochs, but the long-running existence of slavery cannot be denied. ${ }^{2}$

It had already been pointed out by the Romans (the randomly chosen bibliography on Roman slavery includes e.g. Bradley 1994; Buckland 1908; del Prete 1937; Robleda 1976; Watson 1987; Camodeca 2000; Melluso 2000; Starace 2006; Bradley, Cartledge 2011; Korporowicz 2011) that slavery is fundamentally contradictory when analysed from the legal perspective. In Justinian's Institutes, it was declared that slavery has its origins in the law of the nations, while according to natural law everyone should be treated as free (I. 1, 5, pr. See also D. 1, 5, 4, 1 and D. 50, 17, 32). This contradiction became even greater when Christianity appeared. In Saint Paul's epistles, it is possible to find many references to slavery, though it is hard to find any direct castigation of the institution. It is possible, however, to find comments on the mitigation of the severity of owners against slaves (Eph. 6, 9; Col. 4, 1). Still, it is important to remember that the lack of condemnation of slavery in the New Testament was primarily connected with the characteristic of Christianity to change of the way of seeing human destiny. As Saint Paul proclaims on many occasions being a Christian is not a matter of being a Jew, Greek or pagan, or the same as being free or a slave (Gal. 3, 28; Col. 3, 11. See also Harrill 1995; Glancy 2011).

According to R.H. Helmholz, slavery was contrary to natural law and because of this, the medieval Church and the canon lawyers believed it reasonable to do everything to avoid the condition of a slave. There could be, however, no direct statement of the illegality of slavery as a part of the law of nations (Helmholz 2012, 21; see also Epstein 1998). It is interesting that in medieval times, the Church did not openly reject slavery, but it tended to emancipate slaves working in ecclesiastical domains. This habit started to be imitated by the lay lords. With time this caused the extinction of peasant slavery in Europe (Berman 1983, 320).

\section{ANTISLAVERY LITERATURE IN ENGLAND IN $18^{\mathrm{TH}}$ AND $19^{\mathrm{TH}}$ C.}

A new wave of slavery was introduced in the epoch of great geographical discoveries and colonisation. The first black slaves were transported into England as early as the reign of Elizabeth I. The question of slavery was at first of no great importance to English law, since most of the slaves, even if traded by English merchants, remained in the colonies. In the seventeenth century, it was settled that slaves coming to England should be treated as chattels (Baker 2002, 475; Pelteret 1995). It was not until the Asiento agreement (1713), however, that the number of

${ }^{2}$ Although the article focuses on the subject of the abolition of slavery, it must be remembered that Britain also witnessed strong opposition to emancipation (Dumas 2016). 
slaves started to increase significantly in England (Shyllon 1974, 3). Pretty much at the same time, however, slavery and especially the poor condition of slaves heightened the awareness of some individuals. They started to struggle for the emancipation of slaves living in England.

The number of larger works and smaller pamphlets regarding the abolition of slavery gradually grew. In the following part of this article, only a few selected works will be discussed, and with the main focus primarily on the use of or reference to Roman law or Roman antiquity (see e.g. Hodkinson, Hall 2011).

To begin with, it seems reasonable to start with an address published on 19 March 1767 in the Virginia Gazette. Although that antislavery statement was published in colonial America, it contains an interesting reference to Roman law. The address was written by Francis Hutcheson, namesake of a Scottish enlightenment philosopher. The author proclaimed that 'slavery then is a violation of justice, will plainly appear, when we consider what justice is'. The definition of justice, indeed, was borrowed from the famous passage in Justinian's Digest that justice is constans et perpetua voluntas ius suum cuique tribuendi (D. 1, 1, 10, pr.).

In England, at the same time, the first important abolitionist fighter was initiating his activities. Granville Sharp (Shyllon 1974, 18-39; Ditchfield 2004; Lyall 2017) had involved himself first in helping an injured slave named Jonathan Strong during his legal trial. On the back of the case, he had written and published in 1769 a treatise entitled A Representation of the Injustice and Dangerous Tendency of Tolerating Slavery. Although very elaborate, the text contains some limited and indirect Roman crossovers. Sharp himself explained his attitude by saying that: 'the state of Slaves amongst the Romans or other heathen nations, and the imaginary rights of conquerors in those early days to enslave their captives, do not at all concern a Christian government (...) such precedents cannot be of any authority amongst Christians' (Sharp 1769, 6). The Roman comparisons had been rejected by Sharp. Later, he quoted the works of such authors as Grotius and Gronovinus, though both of these writers were discussing Frankish rather than Roman slavery (Sharp 1769, 7). Sharp also cited Pufendorf as authority, but he cited only general remarks of the German scholar on slavery (Sharp 1769, 10). Among the civilians who were quoted by Sharp, the largest number of quotations were attributed to Thomas Wood. Only once, however, did the abolitionist quote Wood's Institutes of civil law (Sharp 1769, 6). On the remaining few occasions he quoted the passages from another book by the same author, i.e. Institute of the Laws of England (Sharp 1769, 14, 19, 21, 22, 24).

It can be clearly seen that at an early stage of writing on emancipation, the idea of citing Ancient Rome as an authority was rejected. But the publication of A Representation was only the beginning of Sharp's literary activity on behalf of slaves. In the following years, he published many other antislavery pamphlets. Among them, an important one for the purposes of this article was entitled 
A Letter to a Gentleman in Maryland, published almost twenty-five years after A Representation. The beginning of the text is predominantly based on Biblical arguments, supplemented with legal as well as theological references to St. German's Doctor and Student. Later some other authorities are quoted, including Sir Edward Coke and Fleta, and finally Sharp focussed on the Roman sources. He pointed out that Fleta's assertion est quidem servitus libertati contrarium, item constitutio quedam de iure gencium qua quis dominio alieno contra naturam subicitur (Fleta 1, 3), is in fact borrowed from Justinian's Institutes (I. 1, 3, 2). Sharp's comment on the Roman origins of the text is certainly unexpected. He proclaimed that such valuable appeals to the foundations of the law cannot restrain the bestial power (belluina potestas) 'of Roman tyranny in any of the ten kingdoms of the beast' (Sharp 1793, 9). The analogy is based on the apocalyptic visions from the Book of Daniel (Dn. 7, 15-28). Nonetheless, Sharp concluded that every 'friend of liberty' should be thankful to Justinian for the antislavery argument. It is interesting also that in Sharp's opinion the argument against slavery should always be twofold: firstly Biblical, and secondly based on the aforementioned civilian statement (Sharp 1793, 9). It seems that a life full of struggling with his proslavery opponents forced Sharp to appreciate Roman reasoning.

Another passionate English abolitionist was John Wesley, the founder of Methodism. In 1774 he had published for a first time an essay titled Thoughts upon Slavery. The Roman reference that appeared in the essay is merely historical. Wesley had written 'it commenced [i.e. slavery - Ł.J.K.] in the barbarous state of Society, and in process of time spread into all nations. It prevailed particularly among the Jews, the Greeks, the Romans, and the ancient Germans: And was transmitted by them to the various kingdoms and states, which arose out of the Roman Empire' (Wesley 1775, 4). This historical illustration of slavery's development did not influence Wesley's argumentation much. In the case of the Roman legal argument, it can be found in Wesley's essay, but only in the form of a long quotation of a relevant passage from William Blackstone's Commentaries (Wesley 1775, 17).

Similar material to that just presented can be found in Joseph Wood's Thoughts on the Slavery of the Negros published in 1784. Wood, who was a supporter of the abolition movement, enumerated in his pamphlet a number of arguments used by adherents of the preservation of slavery. He had written: 'lastly, slavery has always been practised, it is said, amongst the most liberal and enlightened nations, the Greeks, the Romans, and even the Jews under the theocracy'(Wood 1784, 12). Later, however, he noticed that 'slavery amongst Greeks and Romans was frequently mitigated to servitude' (Wood 1784,21 ) and finally he explained his statement by pointing out that Roman slaves were 'indulged with some property of their own' (Wood 1784, 22). Wood also explained that this kind of property was defined by the Romans as the peculium. 
The year 1784 also saw the publication of a much bigger and systematic work concerned with the problem of slavery: James Ramsey's Essay on the Treatment and Conversion of African Slaves in the British Sugar Companies. The Roman references used by Ramsey were barely historic. It is, however, worth quoting a passage from Ramsey's book that well illustrates his attitude towards Roman slavery: 'in the infant state of Rome, slaves worked, and lived with their masters, without much distinction of rank or usage. But in proportion as luxury increased among the Romans, the condition of their slaves sunk gradually down to the lowest degree of wretchedness and misery. And indeed such representation as the statue of the dying gladiator, which exhibits the life of a brave useful man sacrificed, not to the safety of his country, but to the barbarous whim of, perhaps, the most worthless set of men that ever were assembled together in one place' (Ramsey 1784, 25).

Both authors took extreme views of Roman slavery. Wood presented an idealistic and almost romantic vision of slaves working hand by hand with their masters, while Ramsey was convinced about the gradual barbarisation of slavery and its devastating effect on every aspect of human dignity among the Romans as an entire people. There is no need to demonstrate that two such opinions about slavery were exaggerated, though in both of them it is possible to find a grain of truth.

Another author who deserves attention due to his importance to the antislavery cause is Cambridge alumnus Thomas Clarkson (Gibson Wilson 1989). In 1785 he won the first prize for the best dissertation. In the following year, he had enlarged and translated it from Latin into English and entitled it An Essay on the Slavery and Commerce of the Human Species, particularly the African. The book was divided into three parts: (1) 'The History of Slavery', (2) 'The African Commerce or Slave Trade' and (3) 'The Slavery of the Africans in the European Colonies'. Besides the multiple references to Roman history that were inserted into the first part of the book, Clarkson also analysed Roman legal sources. In the seventh chapter of the second part of An Essay, the author discussed the problem of prisoners of war as slaves. At first, he referred to the Digest's passage iure gentium servi nostri sunt, qui ab hostibus capiuntur (D. 1, $5,5,1)$. Clarkson proclaimed that the principle upon which the Roman solution was based was the 'right of capture'. He confirmed that suggestion by referring to Pomponius's passage servorum apellatio ex eo fluxit, quod imperatores nostri captives vendere, ac per hoc servare, nec occidere solent (D. 50, 16, 239). Clarkson made further arguments on the authority of the historians Justin, Cicero and Livy.

A zealous abolitionist of the next generation was William Wilberforce who devoted most of his life to fighting for the emancipation of all slaves both within the Realm as well as in its colonies (see e.g.: Metaxas 2007; Tomkins 2007; Hague 2008). Among his literary works, one deserves close attention. In the year 1807 Wilberforce published A Letter on the Abolition of the Slave Trade, 
Addressed to the Freeholders of Yorkshire. Here, the abolitionist presented a careful analysis of slavery. He discussed in detail the history of the enlargement of the Roman Empire that eventually allowed him to proclaim that the Romans had sold war captives into slavery (Wilberforce 1807, 76-78). Finally, he asserted to his readers that Britons also were the subject of such commerce: 'our own island long furnished its share towards the supply of the Roman market' (Wilberforce 1807, 82).

In the later part of the letter, Wilberforce inserted a paragraph described in the margin as 'West Indian compared with ancient slavery'. He had pointed out that in ancient times slavery played an important role in social and political life and that some slaves were elevated to occupy high offices. Due to this reason, they were - in Wilberforce's opinion - frequently freed. Although his argument relating to the frequency of manumissions can be treated as an exaggeration, it is interesting that the politician added in a footnote the relatively long passage taken from Seneca the Younger's epistle forty-seven, a fundamental Stoic approach to slavery (for more about Seneca's letters see Joshel 2011, 227-230).

The use of similar ancient arguments was also characteristic of Wilberforce during his parliamentary speeches though it may be noted that reference to Roman slavery by Wilberforce was primarily rhetorical. A review of his private correspondence, published in the 1840 s, proves that in everyday life Wilberforce did not seek such fanciful arguments to support his views.

\section{ANTISLAVERY ARGUMENTS IN THE LEGAL WORKS}

Next, to the antislavery propagandists, ancient arguments were also used by the legal authors who supported the abolitionist attempts or at least were simply added to several precedents already decided in English courts.

In Sharp's opinion, his efforts were supported by Sir William Blackstone (Shyllon 1974, 55). It is true that in his Commentaries, Blackstone noticed that 'this spirit of liberty is so deeply implanted in our constitution, and rooted even in our very soil, that a slave or a negro, the moment he lands in England, falls under the protection of the laws, and so far becomes a freeman, though the master's right to his service may possibly still continue' (Blackstone 2002, 123). Blackstone returned to the subject of slavery once more in chapter fourteen of the Commentaries. The chapter entitled 'of Master and Servant' concerns different forms of that relationship, though slavery is described as the first in the list. Blackstone first confirmed his earlier opinion 'that pure and proper slavery does not, nay cannot, subsist in England' (Blackstone 2002, 411). On this basis, he proclaimed that the Roman origins of slavery presented in the Institutes of Justinian (I. 1, 3, 4) are 'false foundations'. The enslavement of captives, according to Blackstone, is against the law of war. He believed 
that it is possible only to kill an enemy in the cases of absolute necessity or self-defence, or to imprison him. Enslavement according to the ius civile is again invalid. Blackstone stated that the sales referred to may mean only the 'contracts to serve or work for another'. And he continued that such enslavement: 'when applied to strict slavery, in the sense of the laws of old Rome or modern Barbary, is also impossible' (Blackstone 2002, 412). In Blackstone's opinion, every contract of sale implies a price and a quid pro quo, which is defined by him as 'an Equivalent given to the Seller in Lieu of what he transfers to the Buyer'. In the author's belief, however, nothing can be given as an equivalent of life and liberty. He noticed also that as the master acquires the whole property of his slave this is also contrary to the contractual relationship. He stated that the 'Buyer gives nothing, and the Seller receives nothing'. In the case of the servi nascuntur circumstance, the lawyer added simply that this prerequisite was built upon two former ones that were already condemned by him as a false.

For that reason, Blackstone solemnly stated that 'the law of England abhors, and will not endure the existence of, slavery within this nation as well as that with the moment when the slave lands on English territory he becomes a freeman'. It is worth mentioning, however, that Blackstone changed his opinion on slavery in one respect. In the first edition of his Commentaries, Blackstone did not include the passage referring to the master's right to a slave's service after his landing in England. This became the subject of controversy and accusation from Sharp (Shyllon 1974, 63-67; Prest 2006, 138-139).

It seems that some reference to Roman law appeared also in the anonymous treatise on Laws Concerning Masters and Servants. This volume was first published in 1767 and was republished again a year later. The author described himself as a 'Gentleman of the Inner-Temple'. The reference to the Roman tradition that appears at the very beginning of the treatise - in its preface - is, in fact, a plagiarism. The author rewrote Blackstone's considerations on Roman slavery, which have already been discussed.

Besides the pure common law approach of Blackstone and his anonymous imitator, it is interesting to look also at the writings of eighteenth-century English civilians. The first author to engage with both the common law and civilian worlds is Thomas Wood (Robinson 1991). He published two systematic works: A New Institute of the Imperial or Civil Law (first edition published in 1704) and An Institute of the Laws of England (in 1720).

In the earlier work, it is much harder to find references to the condition of eighteenth-century slaves according to English law. Nevertheless, Wood proclaimed that 'slaves may claim freedom as they come into England, Germany, France etc.' (Wood 1704, 31). It is surprising to find the statement in a civilian Institute, but it may be interesting that the author based his statement on the work of Vinnius who discussed the problem of prisoners of war. In this context, indeed, the Dutch scholar referred to the relevant passages taken from Justinian's Digest 
(D. 49, 15 and D. 49, 16). The civilian also compared the Roman, English and canonical positions of children born from slave-freeman relationship. For the position in English law, he referred to John Fortescue's Laudibus Legum Angliae and for the canon law, he identified as the source of his knowledge the title $D e$ coniugio servorum of Gregory IX's Decretals (see also Korporowicz 2018, 88). This comparative reflection, however, does not say much either about Wood's pro or con approach to the question of slavery in England or his eventual use of possible arguments against slavery.

Wood's second book, An Institute of the Laws of England, does not help in solving that problem either. In no part of his systematic study of English law does Wood mention the question of slavery. Even the subchapter 'Liberty' that might seem promising at first glance is not helpful, insofar as Wood discussed in it only the question of being free and imprisoned. This lack of slavery-themed considerations is, in fact, interesting from the legal point of view. It means that as late as the $1720 \mathrm{~s}$, the legal condition of slaves was not a pivotal subject of significance for English law.

In the Elements of the Civil Law written by John Taylor thirty-five years later, it is possible to find a great deal of valuable material about Roman slavery. Only occasionally, however, did Taylor decide to link the subject with the problem of slavery in his own times. Indeed, an interesting passage may be found in the essay on servitude. After recalling St. Paul's observations on slavery, Taylor noted that 'several of his Hearers improved upon so comfortable a Doctrine, and gave him some pains to reduce them, and correct their Misapprehensions' and then he added: 'The same Opinion prevails with many at this day, who maintain that Slavery and Christianity are inconsistent, and that Baptism into the Christian Church shall work the Effects of Manumission' (Taylor 1786, 435). In another part of his book, Taylor presented parts of the post-Roman history of slavery, but it seems striking that he avoided comparisons between ancient slavery and the British slave trade.

A very promising tome is Samuel Hallifax's textbook on Roman law published first in 1774. Its subtitle reads: 'An Analysis (...) in which a comparison is, occasionally, made between the Roman laws and those of England'.

In one of the very first chapters of the textbook, dedicated to the subject of freemen and slaves, Hallifax briefly noticed that 'villenage, as formerly known in England, was a state little better than Slavery among the Romans'. Later, the civilian presented some additional information about villeinage. Hallifax's last statement seems, however, to be the most appealing: 'the revival of Domestic Slavery in America affords no proof, that the introduction of a new Slavery into England is now lawful' (Hallifax 1774, 8-9). In spite of expectations generated by his earlier discussion, the aforementioned comparison is the only one that can be found in Hallifax's textbook on Roman and English slavery. 


\section{THE JUDICIAL CASES INVOLVING THE CONDITION OF SLAVES}

The earliest case that is important for this study was decided in the late seventeenth century. According to the decision of Holt CJ in Chamberlain v. Harvey case (1697), from the moment a black slave arrives in England, he 'cannot be demanded as a chattel'. In one of the reports of the case, it is possible to notice a brief reference to the Roman law. The judges were analysing, inter alia, the origins of the enslavement of the slave in question. They pointed out that the slave was born of parents who were already enslaved. They commented: "now the children of such parents are slaves as well as they. So it was amongst the Romans' (Chamberlain $v$. Harvey (1696) 5 Mod. 186, 187; 87 Eng. Rep. 598, 599). A few years later, Holt CJ decided in another case known as Smith v. Brown (a.k.a. Smith v. Gould) that 'as soon as negro comes into England, he becomes free' (Smith v. Brown (1706?) 2 Salk 666; 91 Eng. Rep. 566). In one of the reports of the case, it is possible to find an even more solemn statement: 'the common law takes no notice of negroes being different from other men. By the common law no man can have a property in another' (Smith v. Gould (1706) 2 Ld. Raym. 1274, 1275-1276; 92 Eng. Rep. 338). There is no direct civilian reference in the reports of the case, but it is important to notice that according to the judges the only restrictions on the freedom allowed in English law are villeinage and hostile capture. In the latter, it is possible to detect a slight association with the civilian tradition. Nevertheless, according to Sir John H. Baker, neither of these two cases had an effect on the practice of law (Baker 2002, 475; van Cleve 2006, 617-618).

In the following decades, slavery cases were heard by English judges, but not many of these cases are widely known. Their impact, again, was rather limited. Among these cases was the one of Jonathan Strong. He was an abandoned slave who received much-needed help from Sharp. In fact, Strong's case drew Sharp's attention to the antislavery movement. As to Roman law, however, there are no traces of its use during the proceedings (Lyall 2017, 42-46, 91-100).

In 1772 probably the most famous case concerning slavery, Somerset $v$. Stewart, or Somerset's case, was decided. The principal figure behind the decision was Lord Mansfield.

The official report of the case does not contain any direct references to Roman law, but it is worth noticing that the argument recounted in the official report closely resembles the logic of Blackstone's deliberations aforementioned. The report contains information about captivity and contract as a source of slavery. These passages were based on the relevant fragments of Grotius and Pufendorf (Somerset v. Stewart (1772) Loft 1, 2-3; 98 Eng. Rep. 499, 500). There is no doubt, however, that their thoughts on that matter were based on Roman sources.

${ }^{3}$ For the Scottish eighteenth century cases regarding slavery and the use of Roman law arguments in them see one of the recent works of John Cairns $(2012,68-77)$. 
Although the similarities between Roman and modern (British) slavery were quite tempting and obvious, they do not appear in many late eighteenth century cases. The existence of slavery in $18^{\text {th }}$ century England, however, made it a popular subject of reference in different trials which were not concerned with slavery. Predominantly, it is possible to trace slavery references in the sphere of inheritance law. The example of inheriting slaves or the requirements to be a Roman citizen, adult and freeman were occasionally mentioned (sometimes with the addition of Justinian's sources) by English judges. ${ }^{4}$ Another example of mentioning the slave's condition and their legal situation in Rome was as a parallel to the condition of ordinary servants, as in the case of Newby $v$. Wiltshire decided in $1785 .{ }^{5}$

Finally, in 1824 in Forbes v. Cochrane, it is possible to find a brief reference to Roman law. The judges stated: 'we have the authority of the civil law for saying that slavery is against the rights of nature, Inst. lib. 1, tit. 3, 2' (Forbes v. Cochrane (1828) 2 B \& C 448, 472; 107 Eng. Rep. 450, 459). This one statement allowed the judges to ignore a great deal of material on Roman slavery, merely to utilise it for their antislavery purposes.

It is ironic that after the abolition process finally succeeded in England, a highly controversial decision was issued by the civilian judge Lord Stowell in the High Court of Admiralty. In 1827 in The Slave Grace he proclaimed that although English law does not recognise slavery, a former slave who returns to the place of his origin, where slavery is legal, becomes a slave again (The Slave Grace (1827) 2 Hagg. Adm. 94; 166 Eng. Rep. 179. See also Holdsworth 1952, 688). Roman law was not mentioned in the case. Nevertheless, while commenting on Lord Mansfield's decision in Somerset's case and its later aftermath, Lord Stowell noticed that the rapidness of the change of mind of English lawyers towards slavery "puts one in mind of what is mentioned by an eminent author (...) in the Roman History, "Ad primum nuntium cladis Pompeianae populus Romanus repente factus est alius": the people of Rome suddenly became quite another people' (The Slave Grace (1827) 2 Hagg. Adm. 94, 106; 166 Eng. Rep. $179,183)$. The quotation is taken from Isaac Casaubon's critique of Athenaeus's Deipnosphistae first published in Lyon in 1600 (Casauboni 1600, 267).

\section{CONCLUSIONS}

As has been shown, Roman law and Roman culture as such were regular, but certainly not frequent, elements of antislavery discussions in eighteenth and early nineteenth-century England. Nonetheless, their occurrence was not

${ }^{4}$ Windham v. Chetwynd (1757) 1 Burrow 414, 426; 97 Eng. Rep. 377, 384; Hatton v. Hooley (1773) Loft 122, 129; 98 Eng. Rep. 566, 570; Ridges v. Morrison and Others (1784) 1 Bro. 389; 28 Eng. Rep. 1195.

${ }^{5}$ Newby v. Wiltshire (1785) 4 Dougl. 284; 99 Eng. Rep. 883. 
treated as a mischief, but rather a logical part of the emancipation rhetoric. The struggling advocates of the slave cause rarely referred to the specific issues of Roman slavery law. They were focusing rather on the phenomena as such. Their evaluation, however, was very bipolar. For some of them, ancient slavery was simply a tyrannical institution of oppression. The others, those who were more willing to compare ancient and modern slavery, tried to highlight the brighter side of ancient personal captivity. They were pointing out formal as well as informal modes of honouring slaves (high offices, peculium). Unfortunately, there is a lack of more balanced opinions - the one that could be called the golden mean.

Besides general references to ancient slavery, two legal sources were used more frequently. First, the abolitionists willingly used the famous contrast between slavery according to the law of nations and the law of nature. The second source of debates was the one which dealt with the origins of slavery. It became a subject of criticism for its lack of coherence. After all, the most common "ancient" argument for the abolitionists was a simple comparison of the Roman and modern slave systems.

\section{BIBLIOGRAPHY}

Baker, John H. 2002. An Introduction to English Legal History. $4^{\text {th }}$ ed. Oxford: Oxford University Press.

Berman, Harold J. 1983. Law and Revolution. The Formation of the Western Legal Tradition. Cambridge, MA-London: Harvard University Press.

Blackstone, William. 2002. Commentaries on the Laws of England. A Facsimile of the First Edition of 1765-1769. With an Introduction by Stanley N. Katz. Vol. 1. Chicago-London: University of Chicago Press.

Bradley, Keith. 1994. Slavery and Society at Rome. Cambridge: Cambridge University Press.

Bradley, Keith. Paul Cartledge. Eds. 2011. The Cambridge World History of Slavery. Vol. 1. The Ancient Mediterranean World. Cambridge: Cambridge University Press.

Buckland, William Warwick. 1908. The Roman Law of Slavery. The Condition of the Slave in Private Law From Augustus to Justinian. Cambridge: Cambridge University Press.

Cairns, John W. 2012. "The Definition of Slavery in $18^{\text {th }}$-Century Thinking. Not the True Roman Slavery". In The Legal Understanding of Slavery. From Historical to the Contemporary. Edited by Jean Allain. 68-77. Oxford: Oxford University Press.

Camodeca, Giuseppe. 2000. "Tabulae Herculanenses: riedizione delle emptiones di schiavi (TH 59-62)”. In Quaestiones iuris. Festschrift für Joseph Georg Wolf zum 70. Geburtstag. Edited by Ulrich Manthe, Christoph Krampe. 53-76. Berlin: Duncker und Humblot.

Casauboni, Iacobus. 1600. Animadversionum in Athenaei Dipnosophistas. Lugduni: Apud Antonium de Harsy.

Clarkson, Thomas. 1786. An Essay on the Slavery and Commerce of the Human Species, particularly the African. $3^{\text {rd }}$ ed. London: Printed by J. Phillips.

del Prete, Pasquale. 1937. La responsabilità dello schiavo nel diritto penale romano. Bari: Instituto di diritto romano.

Ditchfield, Grayson M. 2004. "Sharp, Granville". In Oxford Dictionary of National Biography. Vol. 50. 15-18. Oxford: Oxford University Press. 
Dumas, Paula E. 2016. Proslavery Britain. Fighting for Slavery in an Era of Abolition. Basingstoke: Palgrave.

Epstein, Steven A. 1998. "A Late Medieval Lawyer Confronts Slavery: The Cases of Bartolomeo de Bosco". Slavery \& Abolition 20 (3): 49-68.

Gentleman of the Inner-Temple. 1768. Laws Concerning Masters and Servants. $2^{\text {nd }}$ ed. London: Printed for and Sold by W. Owen, R. Baldwin, and W. Griffin.

Gibson Wilson, Ellen. 1989. Thomas Clarkson: A Biography. London: Macmillan.

Glancy, Jennifer. 2011. "Slavery and the Rise of Christianity". In The Cambridge World History of

Slavery. Vol. 1. The Ancient Mediterranean World. Edited by Keith Bradley, Paul Cartledge. 456-481. Cambridge: Cambridge University Press.

Hague, William. 2008. William Wilberforce. The Life of the Great Anti-Slave Trade Campaigner. London: Harper Perennial.

Hallifax, Samuel. 1774. An Analysis of the Roman Civil Law. Cambridge: Printed by J. Archdeacon. Harrill, James A. 1995. The Manumission of Slaves in Early Christianity. Tübingen: Mohr Siebeck. Helmholz, Richard H. 2012. "The Law of Slavery and the European Ius Commune". In The Legal Understanding of Slavery. From Historical to the Contemporary. Edited by Jean Allain. 17-39. Oxford: Oxford University Press.

Hodkinson, Stephen. Edith Hall. 2011. "Appropriations of Spartan Helotage in British Anti-Slavery Debated of the 1790s." In Ancient Slavery and Abolition. From Hobbes to Hollywood. Edited by Edith Hall, Richard Alston, Justine McConnell. 65-102. Oxford: Oxford University Press.

Holdsworth, William S. 1952. A History of English Law. Edited by Arthur L. Goodhart, Harold G. Hanbury. London: Methuen \& Co. Ltd.

Jansson, Dominika Borg. 2015. Modern Slavery. A Comparative Study of the Definition of Trafficking in Persons. Leiden-Boston: Brill Nijhoff.

Joshel, Sandra R. 2011. "Slavery and Roman literary culture". In The Cambridge World History of Slavery. Vol. 1. The Ancient Mediterranean World, edited by Keith Bradley, and Paul Cartledge. 214-240. Cambridge: Cambridge University Press.

Korporowicz, Łukasz J. 2011. "Buying a Slave in Roman Britain. Evidence from the Tabulae". Revue Internationale des droits de l'antiquité 58: 211-224.

Korporowicz, Łukasz J. 2018. "Was the Roman Catholic Canon Law Studied in Eighteenth Century England?" Studia Prawno-Ekonomiczne 108: 83-102.

Lyall, Andrew. 2017. Granville Sharp's Cases on Slavery. Oxford and Portland, OR: Hart Publishing.

Melluso, Marco. 2000. La schiavitù nell'età Giustinianea. Disciplina giuridica e rilevanza sociale. Paris: Presses Universitaires Franc-Comtoises.

Metaxas, Eric. 2007. Amazing Grace. William Wilberforce and the Heroic Campaign to End Slavery. New York: HarperCollins Publishers.

Pelteret, David A.E. 1995. Slavery in Early Mediaeval England. From the Reign of Alfred until the Twelfth Century. Rochester, NY: Boydell \& Brewer.

Prest, Wilfrid R. Ed. 2006. The Letters of Sir William Blackstone. London: Selden Society.

Ramsey, James. 1784. Essay on the Treatment and Conversion of African Slaves in the British Sugar Companies. London: Printed and Sold by James Phillips.

Robinson, Robert B. 1991. "The Two Institutes of Thomas Wood: A Study in Eighteenth Century Legal Scholarship”. American Journal of Legal History 35: 432-458.

Robleda, Olis. 1976. Il diritto degli schiavi nell'antica Roma. Roma: Università Gregoriana Editrice. Sharp, Granville. 1769. A Representation of the Injustice and Dangerous Tendency of Tolerating Slavery in England. London: Printed for Benjamin White, (No. 63) in Fleet-Street, and Robert Horsfield (No. 22) in Ludcate-Street.

Sharp, Granville. 1793. An Extract of a Letter to a Gentleman in Maryland. London: Printed by James Phillips. 
Shyllon, Folarin O. 1974. Black Slaves in Britain. London-New York-Ibadan: Oxford University Press.

Starace, Pia. 2006. Lo statuliber e l'adempimento fittizio della condizione. Uno studio sul favour libertatis fra tarda Repubblica ed età antonina. Bari: Cacucci.

Taylor, John. 1786. Elements to the Civil Law. $3^{\text {rd }}$ ed. London: Printed for Charles Bathurst.

Tomkins, Stephen. 2007. William Wilberforce. A Biography. Oxford: Oxford University Press.

van Cleve, George. 2006. "Somerset's Case and Its Antecedents in Imperial Perspective". Law and History Review 24 (3): 601-646.

Watson, Alan. 1987. Roman Slave Law. Baltimore and London: John Hopkins University Press.

Wesley, John. 1775. Thoughts upon Slavery. $4^{\text {th }}$ ed. Dublin: Printed for W. Whitestone.

Wilberforce, Robert I., Samuel Wilberforce. 1840. The Correspondence of William Wilberforce. 2 vols. London: John Murray.

Wilberforce, William. 1807. A Letter on the Abolition of the Slave Trade, Addressed to the Freeholders of Yorkshire. London: Printed by Luke Hansard \& Sons.

Wood, Joseph. 1784. Thoughts on the Slavery of the Negroes. London: Printed by James Philips.

Wood, Thomas. 1704. A New Institute of the Imperial or Civil Law. London: Printed by W.B.

\section{Łukasz Jan Korporowicz}

\section{RZYM I PRAWO RZYMSKIE W ANGIELSKIEJ LITERATURZE I ORZECZNICTWIE ANTYNIEWOLNICZYM}

Streszczenie. Zniesienie niewolnictwa przez nowożytne państwa było ważnym krokiem zmierzającym do uznania praw człowieka. Imperium Brytyjskie, jak i jego matecznik - Anglia - były jednymi $\mathrm{z}$ głównych organizmów państwowych odpowiedzialnych za wspieranie międzynarodowego handlu niewolnikami. $\mathrm{Z}$ tego względu rozwijający się w nich ruch abolicyjny zasługuje na szczególną uwagę. Argumentacja stosowana przez jego przedstawicieli stanowiła dotąd przedmiot licznych badań. Argumenty filozoficzne, teologiczne czy handlowe przeciwko niewolnictwu są dobrze znane. Należy podkreślić jednak, że dokonanie abolicji miało być krokiem prawnym. Stąd interesujące wydaje się poszukiwanie prawnych argumentów służących potępieniu zniewalania ludzi. Oczywiste jest, że znalezienie odpowiedniego uzasadnienia byłoby trudne. Niewolnictwo była przecież powszechną instytucją społeczną od czasów starożytnych. Jednak uniwersalne zasady prawa rzymskiego, jak i cywilizacji rzymskiej wykorzystane do tworzenia zachodniej tradycji prawa, czynią z prawa starożytnych interesujące źródło odniesień. Głównym celem artykułu jest ustalenie czy odwołania do starożytności rzymskiej stanowiły ważny argument w brytyjskich zmaganiach o zniesienie niewolnictwa.

Slowa kluczowe: prawo angielskie; prawo rzymskie; niewolnictwo; abolicja. 